\title{
ENUMERATION, ISOLATION AND IDENTIFICATION OF BACTERIA AND FUNGI FROM SOIL CONTAMINATED WITH PETROLEUM PRODUCTS USING LAYER CHICKEN DROPPINGS AS AN AMENDMENT.
}

\author{
${ }^{*}$ Ameh, A.A. and Kawo, A.H. \\ Department of Microbiology, Bayero University, Kano \\ P.M.B. 3011 Kano, Kano State - Nigeria \\ *Correspondence author: amehalloysius@gmail.com 08095978200
}

\begin{abstract}
Enumeration, isolation and identification of bacteria and fungi from soil contaminated with petroleum products using layer chicken droppings as an amendment The media used were nutrient agar for total heterotrophic bacterial count, potato dextrose agar for fungi count, serial dilution was carried out and the pour plate technique was employed. Colonial morphology, Gram staining and biochemical test were used for the identification and characterization of the microorganisms. The microbial count of the layer chicken droppings had a total heterotrophic bacteria count of $1.32 \times 10^{7} \mathrm{cfu} / \mathrm{g}$ and Fungi count of $2.07 \times 10^{6}$ cfu/g while soil contaminated with petroleum products had a total heterotrophic bacteria count of $3.19 \times 10^{6} \mathrm{cfu} / \mathrm{g}$ and fungi count of $3.9 \times 10^{5} \mathrm{cfu} / \mathrm{g}$ respectively. The bacterial general isolated were Proteus vulgaris, Klebsiella pseudomonas and Escherichia coli. The fungi isolated were Mucor species, Aspergillus species, Penicillium species and Fusarium species in significant numbers throughout the period of analysis. The implications of these finding is that the microorganisms isolates found in these layer chicken dropping can be useful in the bioremediation of soil contaminated with petroleum products and possibly other oil polluted sites.
\end{abstract}

Key words: Bioremediation, Chicken droppings, Petroleum, contaminated soil.

INTRODUCTION

Microbial degradation is the major mechanism for the elimination of used petroleum products from the environment (Ibe, 1984; Atlas and Bartha, 1992). Barka and Atlas (1977) also reported that the ability to actively decompose specific fractions of petroleum oil is displayed by many microorganisms;

In recent years, many microbial ecologists have identified various microbial species that are effective degrader of hydrocarbons in natural environments. Many of these microbial consortia have been isolated from heavily contaminated areas. However, bacteria play the central role in hydrocarbon degradation. The driving force for petroleum biodegradation is the ability of microorganisms to utilize hydrocarbons to satisfy their cells growth and energy needs. A large number of studies report that low molecular weight alkanes are degraded most rapidly. Mixed cultures carryout more extensive biodegradation of petroleum than pure cultures (Ghazali et al., 2004, Sun et al., 2005; Gerde et al., 2005; Trinidade et al., 2005). In many ecosystems, there is already an adequate indigenous microbial community capable of extensive oil biodegradation provided that environmental conditions are favourable for oil degrading metabolic activity (Capelli et al., 2004; Richard and Vogel, 1999; Kim et al., 2005). There are several advantages relying on indigenous microorganisms rather than adding microorganisms to degrade hydrocarbons. Firstly, natural populations has developed through many years, these microorganisms are adapted for survival and proliferation in that environment. Secondly, the ability to utilize hydrocarbons is distributed among a diverse microbial population. This population occurs in natural ecosystems and either independently or in combination metabolizes various hydrocarbons. Many times when the amount of microorganisms is sufficient in the contaminated environment, microbial seeding is not required. Nutrient availability, especially of nitrogen and phosphorus, seems to be the most limiting factors. It was confirmed that these nutrient enhance growth of microorganisms which leads to more rapid decomposition of contaminants (Chaineau et al., 2005; Coulon et al., 2005). The aim of this study is to enumerate, isolate and identify bacteria and fungi from soil contaminated with petroleum products using layer chicken droppings as an amendment thereby bring about bioremediation. 


\section{MATERIALS AND METHODS \\ Collection of Samples}

The soil samples were collected from a mechanic workshop along Airport road Kano in a sterile dark polythene bag using sterile spatula at the depth of $10 \mathrm{~cm}$. This was transported to the Microbiology laboratory for further processing. The layer chicken droppings was collected from Agrovet poultry farm at Kwakwachi using a sterile plastic container, air dried, ground and stored in the laboratory at room temperature

\section{Biodegradation Experiment}

Contaminated soil sample $(1.2 \mathrm{~kg})$ was sieved, moistened and kept at room temperature. The soil samples $(300 \mathrm{~g})$ were then separated into four (4) glass jar containers, chicken droppings were added to two set up at $5 \%$ and $10 \%$ respectively, $2 \%$ formaline solution was applied to one set up as control 2 and the control 1 (contaminated soil without amendment) and observed for eight (8) weeks at a week interval. Microbiological Analysis

Enumeration of heterotrophic bacteria and fungi was carried out by pour plating technique. This was done by inoculating $0.1 \mathrm{ml}$ tenfold serially diluted samples onto nutrient agar (Bacterial), acidified potato Dextrose agar containing Streptomycin (1mg /100 ml) (fungal) and mineral salt Agar (MSA) (Hydrocarbon degraders). The mineral salt media of Mill et al, 1978 as modified by Okpokwasili and Amanchukwu (1988) contains the following composition in gram per litre of distilled water $\mathrm{NaCl} 10 \mathrm{~g}, \mathrm{MgSO}_{4} .7 \mathrm{H}_{2} \mathrm{O}, 0.42 \mathrm{~g}, \mathrm{Kcl}, 0.29 \mathrm{~g}, \mathrm{~K}_{2}$ $\mathrm{HPO}_{4}, 1.2 \mathrm{~g}, \mathrm{KH}_{2} \mathrm{PO}_{4}, 0.83 \mathrm{~g}, \mathrm{NaNO}_{2}, 0.42 \mathrm{~g}$, Agar -Agar, 15g, PH 7.2 and $2 \mathrm{ml}$ of petrol/diesel. The inoculated nutrient Agar plates were incubated at $37^{\circ} \mathrm{C}$ for 24 hours while the potato dextrose Agar plates were incubated at room temperature for 3-5 days. Observed colonies were counted and expressed as colony forming units per gram (cfug ${ }^{-1}$ ).

Characterization and Identification of Microbial Isolates

The bacterial and fungal isolates were characterized based on their cultural, biochemical properties and microscopic appearances as described by Cheesbrough (2005).

\section{RESULTS}

Table 1 shows the microbial counts in uncontaminated soil, contaminated soil and layer chicken droppings. Layer chicken dropping had the highest count in bacterial $\left(1.32 \times 10^{7}\right.$ Cfug $\left.^{-1}\right)$ and fungal count $\left(2.07 \times 10^{6}\right.$ cfug $^{-1}$ ) while contaminated soil had the lowest count in bacterial $\left(3.19 \times 10^{6} \mathrm{cfug}^{-1}\right)$ and fungal count $\left(3.9 \times 10^{5}\right.$ cfug $\left.^{-1}\right)$ before amendment.
There were significant difference at $\mathrm{P}<0.05$ between layer chicken droppings and contaminated soil before amendment.

Table 2 and 3 shows, the bacterial count in the soil contaminated samples with mean values $2.34 \times 10^{6}$ cfug $^{-1}$ and fungi count with mean value $9.06 \times 10^{5}$ cfug $^{-1}$ while layer chicken droppings $10 \%$ amended with soil contaminated shows a mean value of bacterial count $9.58 \times$ $10^{6} \mathrm{cfug}^{-1}$ and fungal count with mean value of $23.91 \times 10^{5}$, there were significant difference at $\mathrm{P}<0.05$ between layer chicken droppings amended with soil contaminated and soil contaminated unamended.

Table 7 shows that, the highest count of hydrocarbon utilizing bacterial were obtained at $10 \%$ layer chicken droppings amended with soil contaminated with a mean value of $2.32 \mathrm{x}$ $10^{6}$ cfug $^{-1}$ while the least hydrocarbon utilizing bacterial count were obtained in the control sample (sample without layer chicken droppings amendments) with a mean value of $5.74 \times 10^{5}$ cfug $^{-1}$ and the highest hydrocarbon utilizing fungal were obtained at $10 \%$ amendment with a mean value of $1.63 \times 10^{6} \mathrm{cfug}^{-1}$ and the least hydrocarbon utilizing fungal count was obtained in the control sample (sample without layer chicken dropping amended) with a mean value of $3.22 \times 10^{5}$ cfug $^{-1}$. There were significant difference at $\mathrm{P}<0.05$ for both hydrocarbon utilizing bacterial and fungal count in 10\% layer chicken droppings with of contaminated soil unamended.

Occurrence of Microorganisms

Table 8 shows that, Klebsiella, Pseudomonas and Proteus vulgaris occurred most frequently while Escherichia Coli was absent for most part of the soil samples observed. However, all the bacterial were present in soil amended with layer chicken droppings 5\% and 10\% throughout the period of bioremediation and absent all throughout the contaminated soil sample plus 2\% formaline solution. In Table 9, Aspergillus niger. Aspergillus fumigatus and Mucor species were present most frequently in all treatments while Penicillium species and Fusarium species occurred least frequently in contaminated soil and layer chicken droppings respectively and were all absent in contaminated soil sample plus $2 \%$ formaline solution.

\section{DISCUSSION}

The layer chicken droppings used had highest counts $\left(1.32 \times 10^{7}\right.$ cfug $\left.^{-1}\right)$ of bacteria and fungi $\left(2.07 \times 10^{6}\right.$ cfug $\left.^{-1}\right)$ (Table 1$)$. These counts were higher than those reported by Obire and Akinde (2008,) Obire et al, (2008), Ugochukwu et al, 2016. The difference in counts could be due to $\mathrm{pH}$ and organic matter content which could aid the proliferation of microorganisms. 
The bacteria and fungi count were most significant difference $(p<0.001)$ at layer chicken dropping. The bacterial and fungal count of soil samples used from petroleum products contaminated and uncontaminated sites as presented in table 1 showed that the uncontaminated sample with $\left(5.94 \times 10^{6} \mathrm{cfug}^{-1}\right)$ for bacteria and $\left(1.27 \times 10^{6} \mathrm{cfug}^{-1}\right)$ for fungal had higher counts compared to contaminated site with $\left(3.19 \times 10^{6} \mathrm{cfug}^{-1}\right)$ for bacterial and $\left(3.9 \times 10^{5} \mathrm{cfug}^{-1}\right)$ for fungi. There were no significant difference $(p>0.05)$ at soil contaminated with petroleum product and uncontaminated soil. This indicates that the petroleum products in the contaminated sites have adversely affected the growth of the organisms as reported by Eja et al., (2003).

The occurrence of Klebsiella pseudomonas and proteus vulgaris in soil contaminated with petroleum products may be due to their ability to utilize oil as their carbon source (Sira et al, 2010). This may have also been the reason for their presence in the soil even after two (2) months of bioremediation of petroleum products contaminated soil while the fungi most frequently isolated from the amended contaminated soil in the laboratory were genera of Aspergillus and Mucor (table 9). The breakdown of petroleum hydrocarbon by fungi particularly of the genera Aspergillus, Mucor, Penicillium and Fusarium has been reported by several authors (Obire et al, 2008; Ibiene et al, 2011). Aspergillus species in particular are reported to be good producers of cellulose, the enzymes responsible for the breakdown of cellulose in petroleum products (Wong et al, 2008). Fungi are notably aerobic and can also grow under environmentally stressed conditions such as low $\mathrm{pH}$ and poor nutrients status (Daris and Westlake, 1979).

Table 1: Total Heterotrophic microbial counts in layers chicken droppings, contaminated soil and uncontaminated soil (cfu/g) $10^{5}$

\begin{tabular}{lll}
\hline \multicolumn{1}{c}{ SAMPLES } & \multicolumn{1}{c}{ BACTERIA (cfu/g) $10^{-5}$} & \multicolumn{1}{c}{$\begin{array}{c}\text { FUNGI } \\
\text { (Cfu/g) } 10^{-5}\end{array}$} \\
\hline Layers Chicken Dropping & $1.32 \times 10^{7 \mathrm{a}}$ & $2.07 \times 10^{6}$ \\
Contaminated soil & $3.19 \times 10^{6 \mathrm{~b}}$ & $3.9 \times 10^{5}$ \\
Uncontaminated soil & $5.94 \times 10^{6}$ & $1.27 \times 10^{6}$ \\
\hline
\end{tabular}

Table 2: Total bacterial counts in soil contaminated amended soil sample $(5 \%, 10 \%)$ and control after two months of bioremediation

Time (weeks) $\quad$ BACTERIAL COUNT (cfu/g) 10

\begin{tabular}{lllll} 
& & & TREATMENTS \\
& $\mathrm{A}$ & $\mathrm{B}$ & $\mathrm{C}$ & $\mathrm{D}$ \\
\hline 0 & $1.62 \times 10^{6}$ & $5.59 \times 10^{6}$ & $6.17 \times 10^{6}$ & Not detectable growth \\
1. & $1.59 \times 10^{6}$ & $6.27 \times 10^{6}$ & $8.39 \times 10^{6}$ & Not detectable growth \\
2 & $1.88 \times 10^{6}$ & $7.14 \times 10^{6}$ & $8.82 \times 10^{6}$ & Not detectable growth \\
3 & $2.09 \times 10^{6}$ & $7.97 \times 10^{6}$ & $9.13 \times 10^{6}$ & Not detectable growth \\
4. & $2.8 \times 10^{6}$ & $1.05 \times 10^{7}$ & $1.3 \times 10^{6}$ & Not detectable growth \\
5. & $3.39 \times 10^{6}$ & $1.33 \times 10^{7}$ & $1.62 \times 10^{7}$ & Not detectable growth \\
6. & $3.0 \times 10^{6}$ & $1.18 \times 10^{7}$ & $1.41 \times 10^{7}$ & Not detectable growth \\
7. & $2.39 \times 10^{6}$ & $1.13 \times 10^{7}$ & $1.26 \times 10^{7}$ & Not detectable growth \\
Mean & $\pm 2.34 \times 10^{6}$ & $9.23 \times 10^{6}$ & $9.58 \times 19^{6}$ & \\
SD. & 0.06 & 2.85 & 4.71 & \\
\hline
\end{tabular}

Table 3: Total fungi count in soil contaminated, amended soil samples $(5 \%, 10 \%)$ and control soil sample.

\begin{tabular}{lllll}
\hline \multirow{2}{*}{ Time (weeks) } & \multicolumn{4}{c}{$\begin{array}{c}\text { FUNGI COUNTS (cfu/g) } 0^{5} \\
\text { TREATMENTS }\end{array}$} \\
\cline { 2 - 3 } & $\mathrm{A}$ & $\mathrm{B}$ & $\mathrm{C}$ & D \\
\hline 1. & $3.4 \times 10^{5}$ & $8.2 \times 10^{5}$ & $1.3 \times 10^{6}$ & Not detectable \\
2. & $3.8 \times 10^{5}$ & $9.1 \times 10^{5}$ & $1.81 \times 10^{6}$ & Not detectable \\
3. & $6.9 \times 10^{5}$ & $1.12 \times 10^{6}$ & $2.06 \times 10^{6}$ & Not detectable \\
4. & $9.3 \times 10^{5}$ & $1.51 \times 10^{6}$ & $2.3 \times 10^{6}$ & Not detectable \\
5. & $1.06 \times 10^{6}$ & $1.99 \times 10^{6}$ & $2.87 \times 10^{6}$ & Not detectable \\
6. & $1.0 \times 10^{6}$ & $2.14 \times 10^{6}$ & $3.41 \times 10^{6}$ & Not detectable \\
7 & $1.18 \times 10^{6}$ & $1.58 \times 10^{6}$ & $2.88 \times 10^{6}$ & Not detectable \\
Means & $1.67 \times 10^{6}$ & $9.1 \times 10^{5}$ & $2.5 \times 10^{6}$ & Not detectable \\
\pm SD & $9.06 \times 10^{5}$ & $13.72 \times 10^{5}$ & $23.91 \times 10^{5}$ & \\
\hline
\end{tabular}


Special Conference Edition, November, 2017

Table 4: Biochemical characteristics and identification of the bacterial isolates obtained from soil contaminated and layers chicken droppings.

\begin{tabular}{|c|c|c|c|c|c|c|c|c|}
\hline S/No & $\begin{array}{l}\text { Isolates } \\
\text { identification }\end{array}$ & $\begin{array}{l}\text { Grams } \\
\text { Reaction }\end{array}$ & Citrate & Indole & TSIA & $\begin{array}{l}\text { Gas } \\
\text { production }\end{array}$ & Urease & $\begin{array}{l}\text { Isolate } \\
\text { identification }\end{array}$ \\
\hline 1. & $\mathrm{~B}_{2}$ & - & - & + & Acid/Acid & + & - & Escherichia coli \\
\hline 2. & $C_{1}$ & - & + & - & Acid/Acid & + & + & $\begin{array}{l}\text { Klebsiella } \\
\text { pseudomonas }\end{array}$ \\
\hline 3. & $\mathrm{US}_{2}$ & - & + & - & Acid/Acid & - & + & $\begin{array}{l}\text { Klebsiella } \\
\text { pseudomonas }\end{array}$ \\
\hline 4. & $\mathrm{CS}_{3}$ & - & - & + & Acid/Acid & + & - & Escherichia coli \\
\hline 5. & $\mathrm{US}_{1}$ & - & - & + & Acid/Acid & - & - & Escherichia coli \\
\hline 6. & $\mathrm{~F}_{2}$ & - & + & - & Acid/Acid & + & + & $\begin{array}{l}\text { Klebsiella } \\
\text { pseudomonas }\end{array}$ \\
\hline 7. & $\mathrm{CF}_{3}$ & - & - & + & Acid/Acid & + & - & Escherichia coli \\
\hline 8. & $\mathrm{CF}_{2}$ & - & + & - & Acid/Acid & + & + & $\begin{array}{l}\text { Klebsiella } \\
\text { pseudomonas }\end{array}$ \\
\hline 9. & $\mathrm{~F}_{3}$ & - & + & + & Acid/Acid & + & + & Proteus vulgaris \\
\hline 10. & $\mathrm{~F}_{1}$ & - & + & + & $\begin{array}{l}\text { Alkaline/ } \\
\text { Alkaline }\end{array}$ & + & + & Proteus vulgaris \\
\hline 11. & $\mathrm{~F}_{4}$ & - & - & + & $\begin{array}{l}\text { Alkaline/ } \\
\text { Alkaline }\end{array}$ & + & - & Escherichia coli \\
\hline 12 & $\mathrm{CF}_{4}$ & - & - & + & Acid/Acid & + & - & Escherichia coli \\
\hline
\end{tabular}

Table 5: Biochemical characteristics and identification of the petroleum product utilizing bacterial isolates obtained from soil contaminated and layers chicken droppings

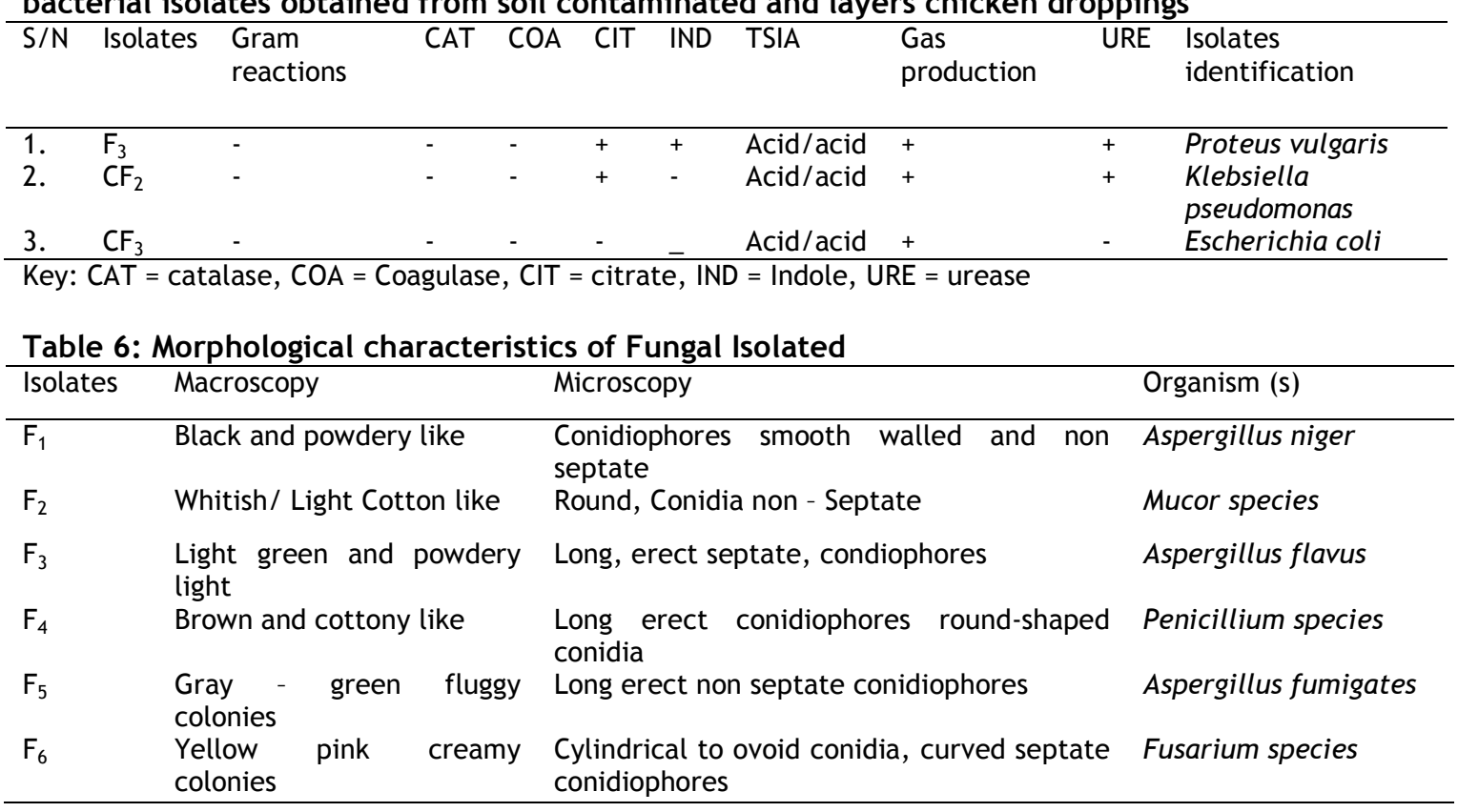


Special Conference Edition, November, 2017

Table 7: Enumeration of Hydrocarbon utilizing microorganisms count in mineral salt medium Time Treatment

(weeks)

Bacteria

Fungi

\begin{tabular}{|c|c|c|c|c|c|c|c|c|}
\hline & A & B & C & D & A & B & C & D \\
\hline 0 & $4.56 \times 10^{5}$ & $1.06 \times 10^{6}$ & $2.01 \times 10^{6}$ & $\begin{array}{l}\text { No } \\
\text { growth }\end{array}$ & $2.44 \times 10^{5}$ & $6.44 \times 10^{5}$ & $1.23 \times 10^{6}$ & $\begin{array}{l}\text { No } \\
\text { growth }\end{array}$ \\
\hline 4 & $\begin{array}{l}5.67 x \\
10^{5}\end{array}$ & $1.17 \times 10^{6}$ & $2.39 \times 10^{6}$ & $\begin{array}{l}\text { No } \\
\text { growth }\end{array}$ & $3.11 \times 10^{5}$ & $7.56 \times 10^{5}$ & $1.48 \times 10^{6}$ & $\begin{array}{l}\text { No } \\
\text { growth }\end{array}$ \\
\hline 8 & $7.0 \times 10^{5}$ & $1.54 \times 10^{6}$ & $2.56 \times 10^{6}$ & $\begin{array}{l}\text { No } \\
\text { growth }\end{array}$ & $4.11 \times 10^{5}$ & $1.49 \times 10^{6}$ & $2.17 \times 10^{6}$ & $\begin{array}{l}\text { No } \\
\text { growth }\end{array}$ \\
\hline Mean & $\begin{array}{l}5.74 x \\
10^{5}\end{array}$ & $1.26 \times 10^{6}$ & $2.32 \times 10^{6}$ & & $3.22 \times 10^{5}$ & $9.63 \times 10^{5}$ & $1.63 \times 10^{6}$ & \\
\hline $\pm S D$ & 1.22 & 2.51 & 2.81 & & 0.84 & 4.59 & 4.86 & \\
\hline
\end{tabular}

Key

$A=$ Soil contaminated with petroleum product only.

$B=$ Soil contaminated with petroleum product plus $5 \%$ layer chicken dropping

C = Soil contaminated with petroleum product plus 10\% layer chicken dropping

$\mathrm{D}=$ Soil contaminated with petroleum product plus $2 \%$ formaline solution.

Table viii: Occurrence of Bacteria in Amended contaminated soil Bacteria isolates

\section{Treatment Time (months)}

\section{Proteus Klebsiella} vulgaris pseudomonas

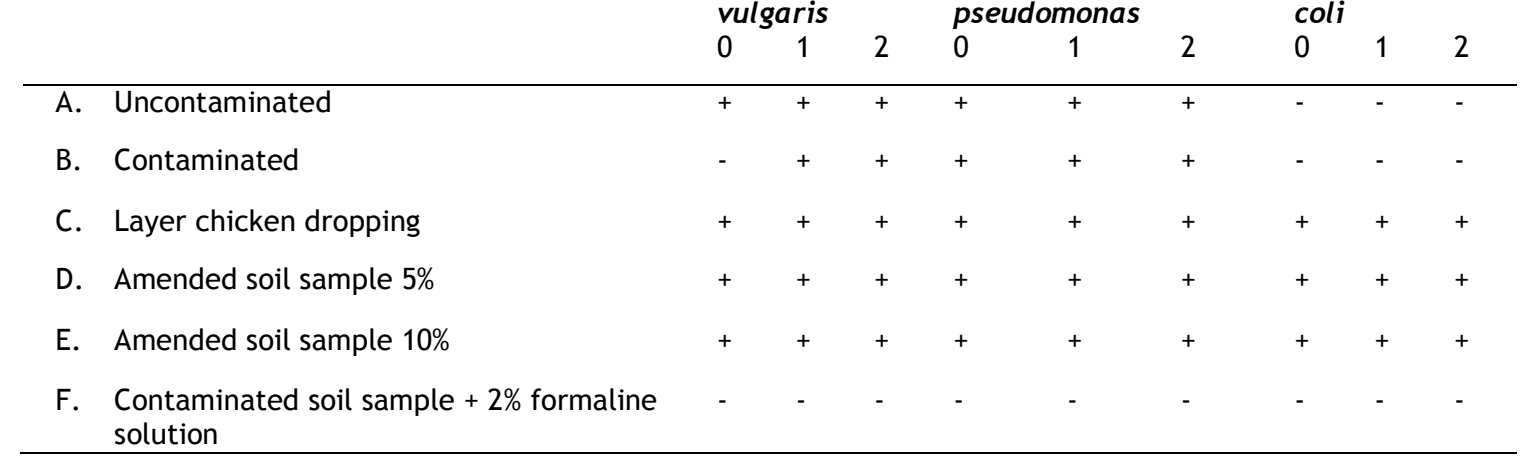

Table 9: Occurrence of Fungi in Amended contaminated soil

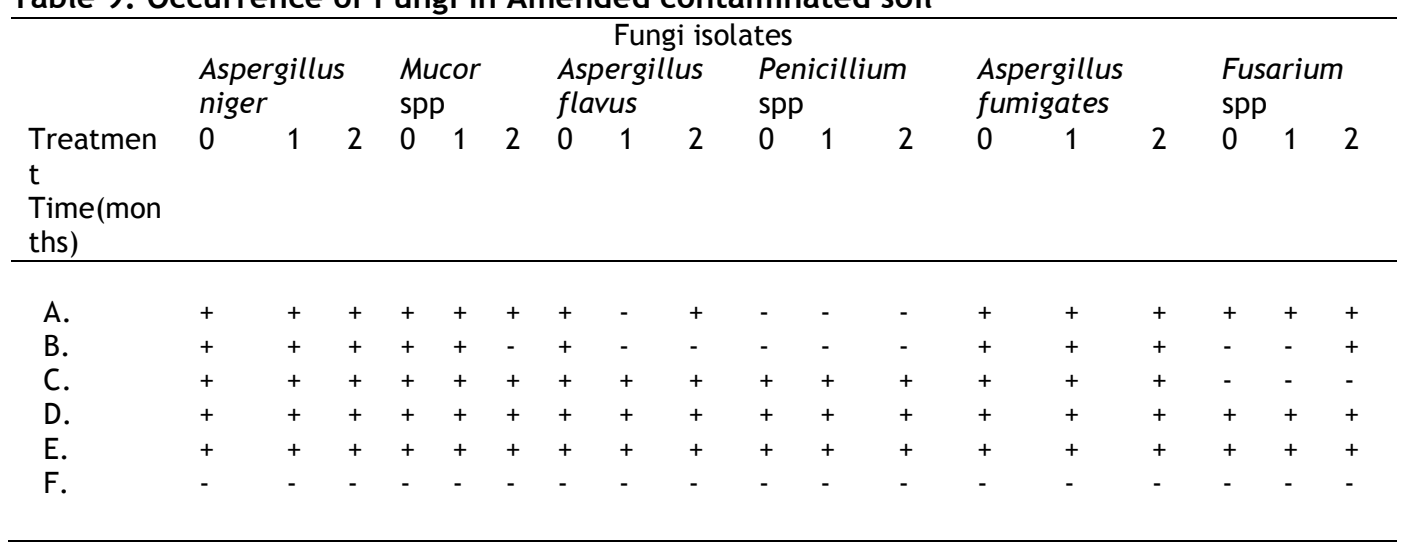

Key:

$+=$ Presence of Fungi

- = Absence of fungi
$A=$ Uncontaminated Soil

$\mathrm{B}=$ Contaminated soil

$\mathrm{C}=$ Layer chicken dropping
$D=$ Amended soil sample $5 \%$

$\mathrm{E}=$ Amended soil sample $10 \%$

$\mathrm{F}=$ Contaminated soil $+2 \%$ 


\section{CONCLUSION}

This study shows that layer chicken droppings have great potentials for the remediation of soils contaminated with petroleum products within a reasonable time, due to the source of nutrients for microbial activity and it habours microorganisms capable of utilizing hydrocarbons as source of carbon and energy

\section{REFERENCES}

Akinde O. and Obire, K. (2008) Aerobic heterotrophic bacteria and petroleum utilizing bacteria from cow dung and poultry manure, world journal microbiology. Biotechnology 24, pp. 1999-2002.

Atlas, R.M and Cerniglia, C.E., (1995), Bioremediation of petroleum pollutants, Biological Science, 45 (5): 332-350.

Atlas, R.M. (1981), Biodegradation of petroleum Hydrocarbon: An environmental perspective microbiological review 45 , $180-209$.

Atlas, R.M. and Bartha, R. 1992, Microbial Ecology: Fundamentals and Applications. Benjamin/Cumming Publishing Company, Inc., Menlo Park, California.

Barka T.J, Atlas R.M. (1977): Ecological aspects of microbial; degradation of petroleum in the marine environment. Applied Environmental Microbiology, $1230-1235$.

Bundy J.G., Paton G.I., and Campbell CD. Combined Microbial community level and single species biosensor responses to monitor recovery of oil polluted soil. Soil Biology and Biochemistry 2004; 36: $1149-1159$.

Capelli S.M., Busalmen PJ., and De Sanchez RS, Hydrocarbon bioremediation of a mineral base contaminated waste from crude oil extraction by indigenous bacteria. International Biodeterioration and Biodegradation 2004; 47: 233 - 238.

Cheesbrough, M. (2005): District Laboratory Practice in Tropical Countries Part 2, UK, Cambridge University Press, Pp. 56, 64-65,69-70.

Chaineau, C.H., Rougeux G, Yepremian C, and Oudot J. (2005). Effect of Nutrient concentration on the biodegradation of crude oil and associated microbial Populations in the soil. Soil Biology and biochemistry. $1-8$

Chukwuma, M.C., Eshett, E.T., Onweremadie, E.U., Okon, M.A., (2010). Zinc availability in relation to selected soil thus, potentially useful in soil contaminated with petroleum products sites, that is, the use of the right types and quantities of nutrients and provision of favourable environmental conditions for the growth of the oil -eating microbes. The use of layer chicken droppings yielded a great degree of bioremediation in the study.

properties in a crude oil polluted entrictropofluvent. International Journal of Environmental Science and Technology, 7 (2), pp. 261 - 270.

Davis, J.B and D.W.S Westlake, 1979 Crude oil utilization by fungi Canadian Journal of Microbiology, 25: $146-156$.

Eja, M.E., Udo, S.M. and Asi Kong, B.E. (2003). Bioremediation potential of Bacillus species in oil polluted. Soil from automechanic workshops in Calabar, Nigeria, Africa J. Environ. Pollute. Health 2 (1): 11 - 18.

Gerhart, P. Murray., R.R.E., Kneg, N.R., Philips, C.B. 1981. Manual of methods of General Bacteriology. American society for Microbiology, Washington D.C.W.A.

Ghazali MF, Zaliha N.R., Abdul R.N., Salleh A.B., and Basir M. Biodegradation of hydrocarbon in soil by Microbial consortium. International Blodeterioration and Biodegradation 2004: 54: 61 - 67

Ibe, D.R., (1984): Evaluation of Microbiological test kits for hydrocarbon fuel system. Applied Environmental microbiology; 37:871 - 877

Ibiene, A. A., F.A. Orji, C.O Ezidi and C. L Ngwobia 2011. Bioremediation of hydrocarbon contaminated soil in the Niger Delta using spent mushroom compost and other organic wastes. Nigeria Journal of Agriculture, Food and Environment, 7 (3): 1 -7.

Kim S.J., Choi D.H. Sin D.S, and Oh Ys. Evaluation of bioremediation effectiveness on crude oil contaminated sand. Chemosphere 2005; 59: $844-852$

Leahy J.G Colwell R.R (1990), Microbial degradation of hydrocarbons in the Environmental Microbial, Rev, 54:305315.

Obire, O. and S.B. Akinde, 2008. Aerobic heterotrophic bacteria and petroleum utilizing bacteria from cow dung and poultry manure. World Journal of Microbiology and Biotechnology, 24:1999-2002. 
Obire, O., E.C Anyanwu and R. N., Okigbo, 2008 saprophytic and crude oil -degrading fungi from cow dung and poultry droppings as bioremediating agents, Journal of Agricultural Technology, 4 (2): $81-89$.

Richard J.Y., and Vogel M.T. Characterization of a soil bacterial consortium capable of degrading diesel fuel. International Biodeteriortation and Biodegradation 1999; 44: 93 - 100.

Riser - Roberts E. Bioremediation of Petroleum contaminated sites. Boca Raton (FL): CRC Press Inc; 1992.

Robert, M.G, J.R. Stephen and C.P. Roger, 2003: Biodegradation of fuel oil under Laboratory and arctic marine conditions. Spl. Sci. Technol. Bull, 8:297-302.

Romantschuk, M., Sarand, I., Petanen, T., Peltola, R., Johnson - Vihanne, M., Koivula, T. 2000. Means to improve the effect of institu bioremediation of contaminated soil; an overview of novel approaches Environmental pollution. 107, 179 - 185.

Sira P.P. Orathai, R. Ratana, K. Boonyarach, S. Pastra and C. Sumaeth, 2010. biosurfactant production by psendomonas aeruginosa $\mathrm{SP}_{4}$ using sequence batch reactors: Effect of oil to glucose ration. Biochemical Engineering Journal, 49; 185 -191.

Sun Y. Chen Z, Xu S and Cai P. Stable carbon and hydrocarbon isotopic fractionation of individual $\mathrm{n}$ - alkanes accompanying biodegradation; evidence from a group of progressively biodegraded oils.
Organic Geochemistry 2005; 36: 225 238.

Trindade, P.V.O., Sobral, L.G., Rizzo, A.C.L., Leite, S.G.F. and Soriano, A.U. (2005). Bioremediation of a weathered and a recently oil contaminated soils from Brazil: A comparison study: Chemosphere, 58: 515 - 522

Ugochukwu C. Okafor, Micheal U. Orji, Kingsley C. Agu, Nsikak S. Awah, Benjamin C. Okeke, Onyedika I. Okafor and Nnenna C.N. Okoro, "Bioremediation of Crude Oil - polluted soil using Broiler Chicken Droppings". Journal of Applied and Environmental Microbiology, Vol. 4, No. 4 (2016): 75 - 84. Doi: 10. 12691/Jaem - 4-4-2.

Walker, J.D. 1976. Enumeration of petroleum Degrading microorganisms. Applied Environmental microbiology. 31, 198 207

Walkley, A and I.A. Black 1934.An Examination of Degtjareff method for Determining Soil Organic Matter and a Proposed Modification of the Chromic Acid Titration method. Soil Sci, 37:29-37.

Wong, K.M, A. A. Nor, A. Suraini, S. Vikineswary and A.H Moh'd 2008. Enzymatic hydrolysis of palm oil mill effluent solid mixed cellulose from locally isolated fungi. Research Journal of Microbiology, 3 (6): $474-481$.

Yeung, P.Y., Johnson, R.L., XU, J. G. 1997. Biodegradation of Petroleum hydrocarbons is soil as affected by healing and forced aeration. Journal of environmental quality. 26, 1511 - 1516. Inc, USA 